\title{
Ductal carcinoma in situ arising within a benign phyllodes tumor: A case report
}

\author{
Benign filloid tümörden gelişen duktal karsinoma in situ, bir vaka sunumu \\ Ali İmran Küçük ${ }^{1}$, Havva Belma Koçer ${ }^{1}$, Şahin Erdem², Ali Bal ${ }^{1}$, Güner Çakmak ${ }^{1}$, Adem Şentürk \\ ${ }^{1}$ Sakarya Üniversitesi Tıp Fakültesi, Genel Cerrahi Ana Bilim Dalı, Sakarya \\ ${ }^{2}$ Sakarya Üniversitesi Tıp Fakültesi, Patoloji Ana Bilim Dalı, Sakarya
}

Dergiye Ulaşma Tarihi:02.10.2017 Dergiye Kabul Tarihi:19.12.2017 Doi: 10.5505/aot.2018.08769

\section{ÖZET}

Filloid tümör (FT), tüm meme tümörlerinin \%1'inden azını oluşturan nadir bir fibroepitelyal neoplazmdır ve fibroepitelyal neoplazmların \% 2-3'ünü oluşturur. FT'ün malign transformasyonu genellikle stromal komponentin de gerçekleşir ve epitelyal komponentde malign transformasyon nadiren görülür. DCIS, LCIS veya invaziv tümörler nadiren de olsa epitelyal komponent kaynaklı olabilir. Biz benign bir FT'de ortaya çıkan duktal karsinoma in situ (DCIS) olgusunu sunuyoruz. 38 yaşında multipar kadın hasta, sol meme üst dış kadranda sınırları belirsiz, düzensiz şekilli, sert, palpabl bir kitle şikayetiyle başvurmuş. Bu kitleden poliklinik koşullarında, ultrason eşliğinde kor biyopsi yapıldı ve biyopsi sonucu DCIS komponenti içeren benign FT olarak geldi. Hastaya segmental mastektomi uygulandi. Patoloji sonucu, duktal karsinoma in situ (DCIS) ile birliktelik gösteren benign filloids tümör şeklinde geldi. DCIS, epitelyal komponentin geniş bir alanı (epitelyal komponentin \% 70'i) içinde gözlendi. Cerrahi sınır tümörden 1 mm uzaktaydı. Hastaya re-eksizyon uygulandı, ancak cerrahi sınır yakın geldi, bu nedenle hastaya implant rekonstrüksiyonu ile subkutan mastektomi uygulandı. Büyük boy filloid tümörler, Malign filloid tümörler veya epitelyal tümör içeren filloid tümörler, onkoplastik cerrahi teknikleri ile negatif cerrahi sınırla rezeke edilebilir. Böylece, filloid tümörlerde onkolojik ve kozmetik olarak başarılı sonuçlar elde etmek mümkündür.

Anahtar Kelimeler: Filloid tümör, Duktal Karsinoma İn situ, Onkoplastik Cerrahi

\begin{abstract}
Phyllodes tumor (PT) is a rare type of biphasic fibroepithelial neoplasm that accounts for $<1 \%$ of all breast tumours and represents $2-3 \%$ of fibroepithelial neoplasms. Malignant transformation of PT usually occurs in the stromal component, and is rare in the epithelial component. DCIS, LCIS or invasive tumors might be due to epithelial component. We report a case of ductal carcinoma in situ (DCIS) occurring with in a benign PT. A 38-year-old multipar woman applied to an other medical center with compliants of a firm, palpable, irregularly-shaped lump with an ill-defined margin in the outer upper quadrant of the left breast. An ultrasound-guided core biopsy of this lump was done on an outpatient basis and the biopsy findings were benign PT with a DCIS component. The patients has undervent segmental mastectomy. The patology results were benign phyllodes tumor with Ductal Carcinoma In situ (DCIS). DCIS was also observed in a wide area of epithelial component (70\% of epithelial component). The surgical margin were $1 \mathrm{~mm}$ away from the tumor. The patients had re-excision operation, however the surgical margin was still closed the margin so the patient had subcutaneous mastectomy with implant reconstruction. Large sized phyllodes tumors, malign phyllodes or epithelial tumors within phyllodes tumor can be resected with negative surgical margin with oncoplastic surgery techniques. Thus, it is possible to obtain successful results both in oncologic and cosmetically in phyllodes tumors.
\end{abstract}

Keywords: Phyllodes tumor, Ductal Carcinoma İn situ, Oncoplastic Surgery

\section{INTRODUCTION}

Phyllodes tumor (PT) is a rare type of biphasic fibroepithelial neoplasm that accounts for $<1 \%$ of all breast tumours and represents $2-3 \%$ of fibroepithelial neoplasms $(1,2)$. PT is classified as benign, borderline or malignant, with approximately $10 \%$ of PT being malignant. It is a combined fibroepithelial tumor in which the mesenchymal, or stromal, component is more hypercellular than an adenofibroma. 
Assessment of malignant potential of cystosarcomas traditionally has been based on the microscopic features of the stromal cells, which may appear entirely innocuous in some tumors and unequivocally sarcomatous in others. Malignant transformation of PT usually occurs in the stromal component, and is rare in the epithelial component. DCIS, LCIS or invasive tumors might be due to epithelial component. The tumors may be small or very large, ranging in size from 1 to $45 \mathrm{~cm}$ (3). Surgery is considered the standard treatment for PT (4). To the best of our knowledge, only nine cases of benign phyllodes tumors with ductal carcinoma in situ have been reported in the literature. We report a case of ductal carcinoma in situ (DCIS) occurring with in a benign PT in a 38-year-old woman.

\section{CASE PRESENTATION}

A 38-year-old multipar woman applied to an other medical center with compliants of a firm, palpable, irregularly-shaped lump with an illdefined margin in the outer upper quadrant of the left breast. The tumor was presented as $7 \mathrm{~cm}$ benign lump in the left upper outer quadrant, fairly mobile and not attached to any underlying structures or overlying skin. Axillary examination was normal. An ultrasound-guided core biopsy of this lump was done on an outpatient basis and the biopsy findings were benign PT with a DCIS component.

The patient underwent local excision with a $1 \mathrm{~cm}$ margin from tumor edge. The macroscopic examination revealed a hard elastic mass, which was encapsulated by thin fibrous tissue. The overall size of the PT was $6 \times 5 \mathrm{~cm}$. A histopathological examination showed that the tumor had two components; epithelium and stroma (Fig. 1 ). In stroma, no necrosis or haemorrhage was identified. The mitotic index was very low (1-3 x $10 \mathrm{hpf})$ and the tumour was classified as a benign PT. DCIS was also observed in a wide area of epithelial component (70\% of epithelial component) (Fig.2). The results of immunohistochemical staining of the DCIS cells were as follows; Estrogen receptor positive (70\%), progesterone receptor positive $(90 \%)$ and HER-2 positive (scor3) and $1 \mathrm{~mm}$ from tumor edge. The patient applied our clinic with these results. We decided to reexcision in order to get tumor free margins and axillary sentinel lymph node (SLN) biopsy.
Frozen SLN biopsy result was negative. Reexcision pathology report was high grade DCIS with wide comedo-necrosis and DCIS was 1 $\mathrm{mm}$ away from posterior surgical margin and 1 $\mathrm{mm}$ away from inferior surgical margin. DCIS areas were common in the left breast, second segmental mastectomy has resulted with bad cosmesis (Fig.3). So as we discussed in the our multi-disciplinary meeting, the patient underwent subcutaneous mastectomy with prosthesis reconstruction and right breast reduction mammoplasty at the same operation (Fig-4). After this operation, pathology result was fibrocystic changes.

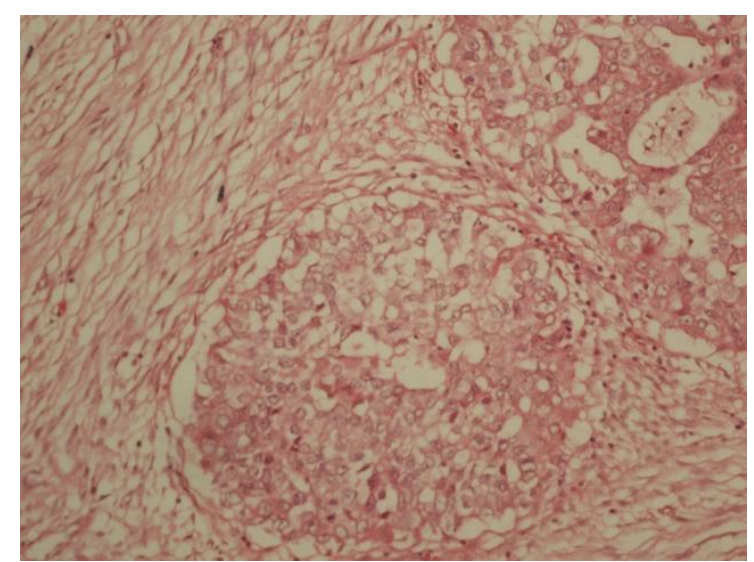

Figure 1: Phyllodes tumor epithelial and stromal component (20X).

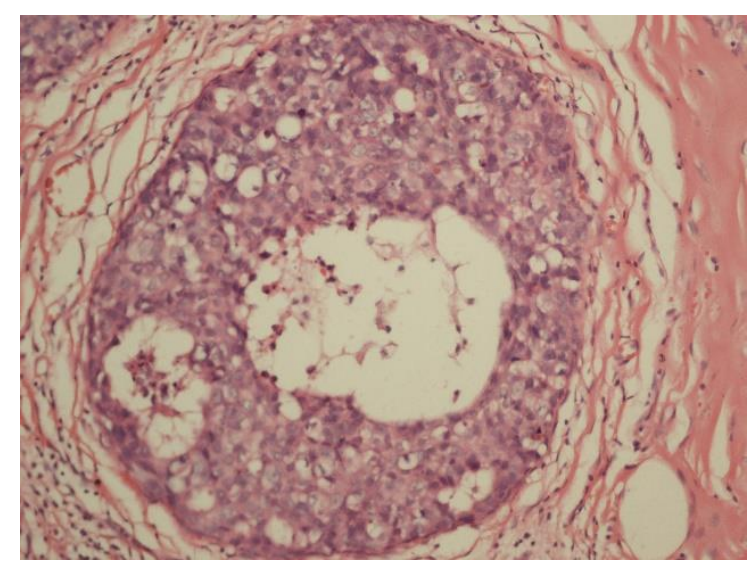

Figure 2: High grade DCIS (20X) 


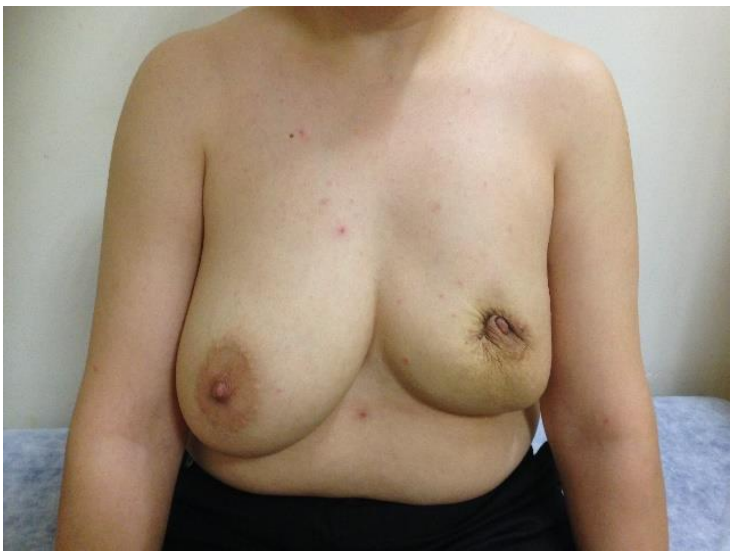

Figure 3: After the re-excision, the cosmetic results of patient

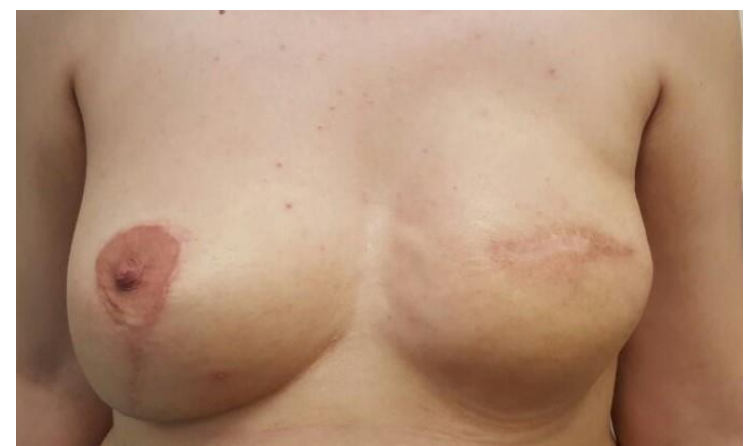

Figure 4: The patients cosmetic results at postoperative 6 months after left subcutaneous mastectomy with impant reconstrcution and right mamoplasty operation.

\section{DİSCUSSION}

Phyllodes tumors are most common between the ages of 40 and 50 years and can sometimes present just like fibroadenoma. They have the tendency to grow rapidly and are broadly classified into three distinct groups; benign, borderline and malignant(5). The epithelial component of phyllodes tumors may show a range of metaplastic and proliferative changes (6). Sawyer et al. showed hyperplasia in the epithelial component of PT in $60 \%$ in their cases (7). In our case; high grade DCIS was seen in $70 \%$ of the epithelial component. The epithelial component as well as the stromal component should be carefully examined pathologically in phylloid tumors.

As carcinoma within a PT is very rare, treatment and follow- up of these cases are not standardized. It is recommended that the treatment be customized in each case based on whether there is an invasive component, affected lymph nodes or distant metastases, and that the carcinomatous component be treated independently of the PT $(8,9)$. Axillary lymph node dissection is not part of the standard treatment for phyllodes tumors as lymph node spread is rare. Also, lymph node metastases associated with a carcinoma, within a PT, are extremely rare; to our knowledge, only two cases have been reported $(10,11)$. The prognosis for cases of carcinoma within benign PT is generally favorable; however, the prognosis for a malignant phyllodes tumor may be more guarded (12).

To the best of our knowledge, until the present case study, there had been only nine such reported cases of benign phyllodes with ductal carcinoma in situ. Leong and Meredith, reported first ever case in 1980 of a 49-year-old woman having ductal carcinoma in situ arising in benign phyllodes tumor (6). Only one younger case of 19 years of age with DCIS arising in benign PT of breast has been reported before (13). A case reported non invasive ductal carcinoma arising in malignant PT in a 75-yearold lady (9). In a reported case of high grade invasive ductal breast cancer within a malignant PT in a 70-year-old woman and another case of invasive ductal carcinoma in a borderline PT with isolated carcinoma cells in the sentinel lymph node of a young woman $(12,13)$. Neto et al., noticed an interesting case of synchronous coexistence of benign PT in one breast and invasive carcinoma in the other breast in a 66year-old multiparous lady (14). However, reported cases of benign PT with invasive or noninvasive ductal carcinoma are much rarer Nio and coworkers described a case of DCIS arising within a benign PT in a 53-year-old female (15). Similarly, our case is one of those rare cases showing features of DCIS in a case of PT.

A variety of therapies were applied to various cases. These are local excision, oncoplastic surgery and local radiation therapy, mastectomy, and axillary lymph node dissection. It appears that oncoplastic surgery, mastectomy or local excision was selected according to the size of phyllodes tumor. Large sized phyllodes tumors, malign phyllodes tumors and epithelial tumors within the phyllodes tumors can be resected with negative surgical margin with oncoplastic surgery techniques. Thus, it is possible to obtain 
successful results both in oncologic and cosmetically in phyllodes tumors.

Financial disclosure: We did not receive financial support for this article.

Conflict of interest: In the article, there is no conflict of interest in any.

\section{REFERENCES}

1. Yamaguchi R, Tanaka M, Kishimoto $\mathrm{Y}$, Ohkuma K, Ishida M and Kojiro M: Ductal carcinoma in situ arising in a benign phyllodes tumor: Reprt of a case. Surg Today; 2008 38:4245.

2. Padmanabhan V, Dahlstrom JE, Chong GC and Bennett G: Phyllodes tumor with lobuler carcinoma in situ and liposarcomatous stroma. Pathology 29: 1997, 224-226.

3. Moinfar F. Biphasic tumors. In: Moinfar F, editor. Essential of Diagnostic Breast Pathology: A Practical Approach. New York, NY: Springer; 2007, 320-50, pp.

4. Schwickerath J, Blessing MH and Wolff F: A rare clinical manifestation of a combination tumor of cystosarcoma phyllodes malignum and an intraductal cancer. Geburtshilfe Frauenheilkd 52: 1992, 557-559 (In German).

5. F. C. Koerner, Phyllodes tumor, in: F. C. Koerner (Ed.), Diagnostic Problems in Breast Pathology, Saunders, Elsevier, Philadelphia, PA; 2009, 329-341, pp.

6. A. S. Leong, D. J. Meredith, Tubular carcinoma developing within a recurring cystosarcoma phyllodes of the breast, Cancer 46, 1980; 1863 1867.

7. Sawyer EJ, Hanby AM, Rowan AJ, Gillett CE, Thomas RE, Poulsom R, et al. The Wnt Pathway, epithelial-stromal interactions, and malignant progression in phyllodes tumors. $\mathbf{J}$ Pathol. 196 (4): 2002; 437-44.
8. Chopra S, Muralikrishnan V, Brotto M. Youngest case of ductal carcinoma in situ arising a benign phyllodes tumor: A case report. Int J. of Surgery. 2016, 67-69.

9. Macher- Goeppinger S, Marme F, Goeppert B, Penzel R, Schirmacher P, Sinn HP, et al. Invasive ductal breast cancer within a malignant phyllodes tumor: Case report and assessment of clonality. Hum Pathol. 2010;41: 293-6.

10. Nomura M, Inoue $Y$, Fujita S, Sakao J, Hirato $\mathrm{M}$, Souda S, et al. A case of noninvasive ductal carcinoma arising in malignant phyllodes tumor. Breast Cancer. 2006; 13: 89-94.

11. Parfitt JR, Armstrong C, O'malley F, Ross J, Tuck AB. In-situ and invasive carcinoma within a phyllodes tumor associated with lymph node metastases. World J Surg Oncol. 2004;2:46.

12. Korula A, Varghese J, Thomas M, Vyas F, Korula A. Malignant phyllodes tumor with intraductal and invasive carcinoma and lymph node metastasis. Singapore Med J. 2008;49: e318-21.

13. Colakoglu MK, Yenidogan E, Akgul GG, Irkkan SC, Ozdemir Y, Gulcelik MA, et al. In Situ Ductal Carcinoma Arising in Benign Phyllodes Tumor in 19-Year Old Patient: A Case Report. J Breast Health. 2014;10(4): 239-41.

14. Neto GB, Rossetti C, Souza NA, LA Fonseca F, Azzalis LA, Junqueira VB, et al. Coexistence of benign phyllodes tumor and invasive ductal carcinoma in distinct breasts: Case report. Eur J Med Res. 2012;17:8.

15. Nio $Y$, Iguchi $C$, Tsuboi $K$, Maruyama $R$. Ductal carcinoma in situ arising within a benign phyllodes tumor: A case report with a review of the literature. Oncol Lett. 2011;2:223-8 